Laporan Kasus

\title{
PRIMARY CUTANEOUS DIFFUSE LARGE B CELL LYMPHOMA-LEG TYPE DENGAN PENYEBARAN EKSTRAKUTAN YANG BERAKIBAT FATAL
}

\author{
Diah Prabawati Retnani ${ }^{\star 凶}$, Eviana Norahmawati ${ }^{\star}$, Hery Susilo**
}

\begin{abstract}
Abstrak
Primary cutaneous B-cell lymphoma (PCBCL) merupakan penyakit keganasan sel limfosit B primer pada kulit yang langka dengan gambaran klinikopatologi, imunofenotipik dan prognosis yang bervariasi. Insiden PCBCL terjadi antara 20\%-25\% dari semua limfoma kulit primer dan jarang bermetastasis ekstrakutan. Dilaporkan satu kasus subtipe PCBCL yaitu primary cutaneous diffuse large B cell lymphomaleg type (PCDLBCL-leg type) yang cukup fatal dengan metastasis ekstrakutan. Seorang laki-laki 46 tahun dengan massa di pergelangan tungkai kanan, selama 1,5 tahun, sebagian berulkus. Empat bulan terakhir terdapat penyebaran massa pada kelenjar getah bening inguinal dan leher. Laporan kasus ini bertujuan untuk mengetahui peranan IHK dalam menentukan diagnosis definitif DLBCL-leg type dan cara menyingkirkan beberapa diagnosis bandingnya yang memiliki tatalaksana dan prognosis berbeda. Hasil USG menunjukkan metastasis pada lien. Pemeriksaan histopatologi biopsi terbuka menunjukkan proliferasi sel-sel berinti bulat, berukuran besar, anak inti prominen, tersusun difus pada dermis mencurigakan non Hodgkin lymphoma (NHL) dengan diagnosis banding melanoma maligna tipe amelanotik. Hasil pemeriksaan imunohistokimia menunjukkan ekspresi positif kuat dan difus terhadap antibodi LCA, CD20, Bcl2 serta negatif terhadap antibodi Melan A dan S100. Indeks proliferasi sel tumor $>40 \%$ dengan pulasan antibodi Ki67. Dari kasus ini dapat disimpulkan bahwa pada pasien laki-laki dewasa dengan massa multipel berulkus di pergelangan tungkai harus dipertimbangkan diagnosis limfoma kutan primer jenis PCDLBCL-leg type bila pemeriksaan histopatologi menunjukkan gambaran pola malignant round cell tumor dengan hasil pulasan imunohistokimia positif kuat dan difus terhadap antibodi LCA, CD20 dan Bc12 serta indeks proliferasi sel tumor yang tinggi.
\end{abstract}

Kata kunci: Bc12, CD20, imunohistokimia, indeks proliferasi, LCA, PCBLC

\section{PRIMARY CUTANEOUS DIFFUSE LARGE B CELL LYMPHOMA-LEG TYPE WITH FATAL EXTRACUTANEOUS INVOLVEMENT}

\begin{abstract}
Primary cutaneous B-cell lymphoma $(\mathrm{PCBCL})$ is a rare $\mathrm{B}$ cell lymphocytes malignancy with various clinicopathological features, immunophenotype characteristics, and prognosis. The incidence of PCBCL is about $20-25 \%$ of all primary cutaneous lymphoma and rarely extracutaneous metastasizes. We report a fatal case of PCBCL's subtype, Primary cutaneous diffuse large B cell lymphoma-leg type (PCDLBCL-leg type), which had extracutan involvement. A 46 years old man with multiple masses in his right lower leg for 1,5 years with some ulcerated area. Last 6 months the mass was spread into inguinal and cervical lymph nodes. This case report aims to describe the role of IHC in determining the definitive diagnosis of DLBCL-leg type and how to rule out several differential diagnoses that have different treatment and prognoses. Histopathological examination of an open biopsy showed the proliferation of nucleated cells with large, prominent nuclei, diffusely arranged in the dermis, suspicious for non-Hodgkin lymphoma (NHL) with a differential diagnosis of amelanotic malignant melanoma. The ancillary testing with immunohistochemistry (IHC) revealed strong and diffuse positivity expression for LCA, CD20, Bcl2 antibodies and negative immunostaining for Melan A and S100. The proliferation index of tumor cells by Ki67 was about $>40 \%$. It can be concluded that in this patient with multiple ulcerated masses on the ankles, the diagnosis of PCDLBCL-leg type primary cutaneous lymphoma should be considered if the histopathological examination shows a malignant round cell tumor pattern with strong and diffuse positive immunohistochemical results for LCA, CD20 antibodies and $\mathrm{Bcl} 2$ also high tumor cell proliferation index.
\end{abstract}

Keywords: Bc12, CD20, immunohistochemistry, LCA, PCBLC, proliferation index

* Departemen Patologi Anatomi, Fakultas Kedokteran, Universitas Brawijaya

** Departemen IImu Bedah, Fakultas Kedokteran, Universitas Brawijaya

凶E-mail: diah_pa@ub.ac.id 


\section{Pendahuluan}

Primary cutaneous diffuse large B-cell lymphoma-leg type (PCDLBCL-leg type) merupakan subtipe primary cutaneous lymphoma yang sangat langka dengan angka kejadian 4\%.1,2 Primary cutaneous lymphoma merupakan keganasan dari sel limfoid dikenal dengan sebutan Non hodgkin lymphoma (NHL) - yang terjadi primer pada kulit tanpa disertai keterlibatan ekstrakutan pada saat diagnosis ditegakkan. ${ }^{1}$ Primary cutaneous lymphoma terbagi atas keganasan jenis sel limfoid $B$ dan $T$. Keganasan jenis sel $B$ pada kulit dikenal dengan sebutan primary cutaneous $B$ cell lymphoma ( $\mathrm{PCBCL})$, sedangkan pada sel $\mathrm{T}$ dikenal dengan primary cutaneous $T$ cell lymphoma (PCTCL). Primary cutaneous Bcell lymphoma (PCBCL), seperti juga halnya PCTCL, memiliki subtipe yang bersifat indolen dan intermediate dengan gambaran klinis, histopatologi serta profil immunofenotipik yang berbeda. Subtipe indolen dari PCBCL cenderung tumbuh lambat, biasanya terjadi hanya pada kulit untuk waktu yang sangat lama, sedangkan subtipe intermediate seperti PCDLBCL-leg type dapat menyebar ke organ lain ekstrakutan. ${ }^{3}$ Perbedaan prognosis dan terapi pada masing-masing subtipe PCBCL menyebabkan ketepatan diagnosis subtipe penyakit ini menjadi sangat penting. 2,3 Pemeriksaan histopatologi dan imuno- histokimia (IHK) sangat diperlukan untuk menentukan diagnosis dan prognosis subtipe PCBCL berdasarkan klasifikasi terbaru menurut World Health OrganizationEuropean Organization for Research dan Treatment of Cancer (WHO-EORTC) tahun 2017.1,2,3,4 Pada laporan kasus ini dipaparkan aspek klinikopatologi serta imunofenotipik dalam menegakkan diagnosis $P C B C L$ jenis PCDLBCL-leg type dengan penyebaran ekstrakutan yang berakibat fatal. Laporan kasus ini bertujuan untuk menjelaskan peran IHK dalam menentukan diagnosis definitif DLBCL-leg type dan cara menyingkirkan beberapa diagnosis bandingnya yang memiliki tatalaksana dan prognosis berbeda.

\section{Kasus}

Dalam penulisan laporan kasus ini pasien telah menandatangani informed consent. Pasien adalah seorang laki-laki yang datang ke RS di Probolinggo, Jawa Timur dengan keluhan benjolan di tungkai kanan bawah bertambah besar, membentuk luka borok yang mudah berdarah dalam 4 bulan terakhir. Benjolan tersebut berawal 1,5 tahun yang lalu sebesar jagung dan tidak pernah periksa ke dokter. Pasien mulai merasakan badan lemah, berat badan menurun kemudian muncul benjolan dilipat paha dan kedua leher setelah benjolan di kaki mulai mudah berdarah (Gambar 1).
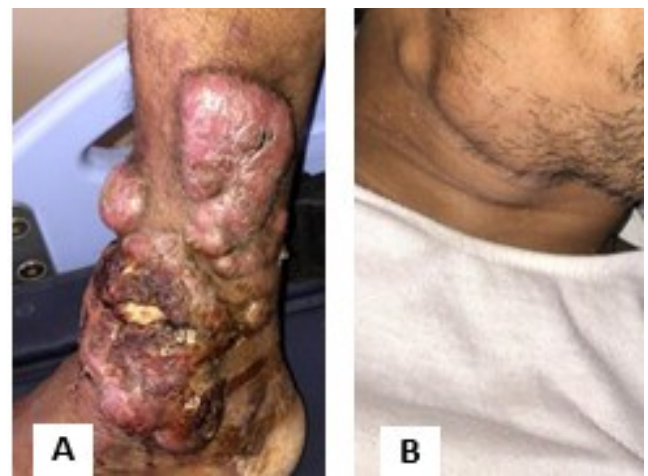

Gambar 1. Gambaran klinis pasien PCDLBCL-leg type

Keterangan: A. Tampak benjolan di tungkai kanan, kemerahan, batas tidak jelas, ulseratif; B. Terlihat pembesaran KGB leher sebagai penyebaran ekstrakutan. 
Hasil pemeriksaan darah lengkap menunjukkan kadar $\mathrm{Hb}$ 9,6 mg/dL, WBC $18170 / \mathrm{mL}$ dan platelet $314000 / \mathrm{mL}$. Pasien menjalani biopsi terbuka dan dicurigai sebagai melanoma maligna tipe amelanotik dengan diagnosis banding NHL. Selanjutnya pasien dirujuk ke RSUD Dr. Saiful Anwar Malang untuk pemeriksaan IHK.

Sediaan biopsi dilakukan potong ulang blok dan diagnosis histopatologi. Hasil pemeriksaan histopatologi menunjukkan malignant round cell tumor yang tersusun difus dalam dermis, terdiri dari proliferasi selsel berinti bulat, sedikit pleomorfik, kromatin kasar dengan anak inti berada di tengah (imunoblas) dan di tepi membran inti (sentroblas) (Gambar 2).

Di antara sel tumor dengan epidermis terdapat area fibrosis yang disebut grenz zone. Gambaran histopatologi jaringan tumor mengarah pada non Hodgkin lymphoma (NHL) yang kemungkinan berasal dari kutan dan menyebar ke ekstrakutan yaitu kelenjar getah bening inguinal dan leher. Hasil pemeriksaan kadar LDH $1497 \mathrm{~m} / \mathrm{L}$, juga mendukung diagnosis NHL secara klinis dan histopatologi. Pemeriksaan IHK dilakukan untuk menyingkirkan diagnosis banding dengan hasil negatif pada pewarnaan antiboodi Melan A dan S100. Pewarnaan LCA dan CD20 terekspresi positif pada membran dan sitoplasma sel tumor sehingga ditegakkan diagnosis primary cutaneous $B$ cell lymphoma (PCBCL). Setelah dilakukan korelasi melalui clinicopathological conference (CPC), terungkap bahwa dari USG abdomen terdapat gambaran metastasis pada lien.

Pemeriksaan IHK menggunakan antibodi Bcl2 dan Ki67 dilanjutkan untuk menegakkan diagnosis jenis subtipe dari PCBCL dan memprediksi prognosis pasien. Hasil pewarnaan $\mathrm{Bcl} 2$ terekspresi kuat pada membran inti sel tumor dan Ki67 positif lebih dari 40\% (high proliferation index) (Gambar 3). Namun, pasien meninggal saat diagnosis ditegakkan .
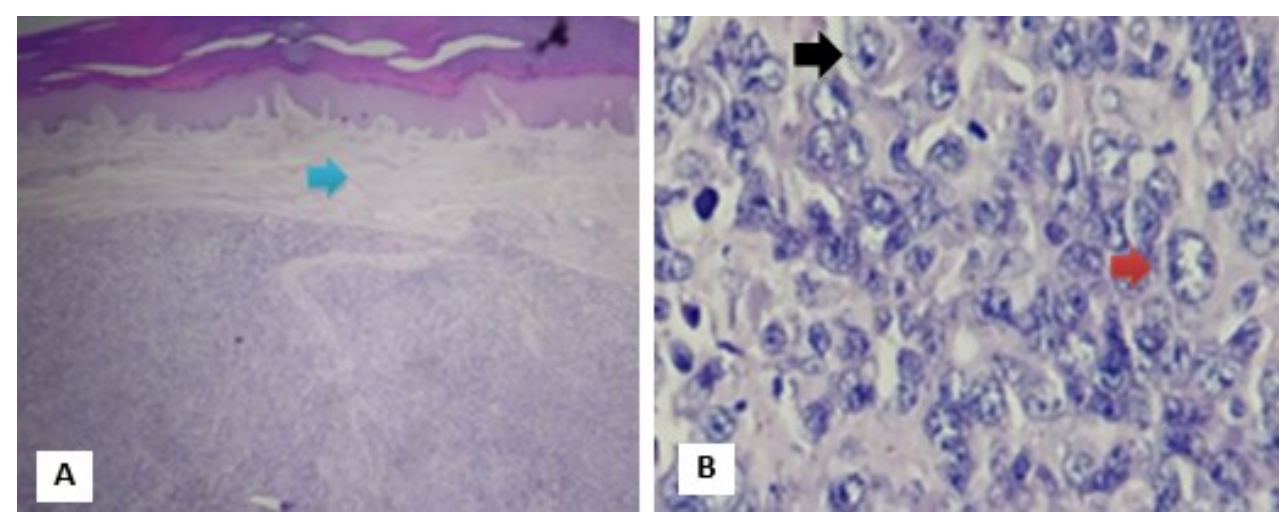

Gambar 2. Histopatologi jaringan tumor

Keterangan: A. Tumor tumbuh pada dermis dibatasi grenz zone antara sel tumor dengan epidermis (panah biru), B. Tampak proliferasi sel-sel berinti bulat, terdiri dari campuran imunoblas (panah hitam) dan sentroblas (panah merah) yang tersusun difus (pewarnaan $\mathrm{HE}$, pembesaran 100x dan 400x). 

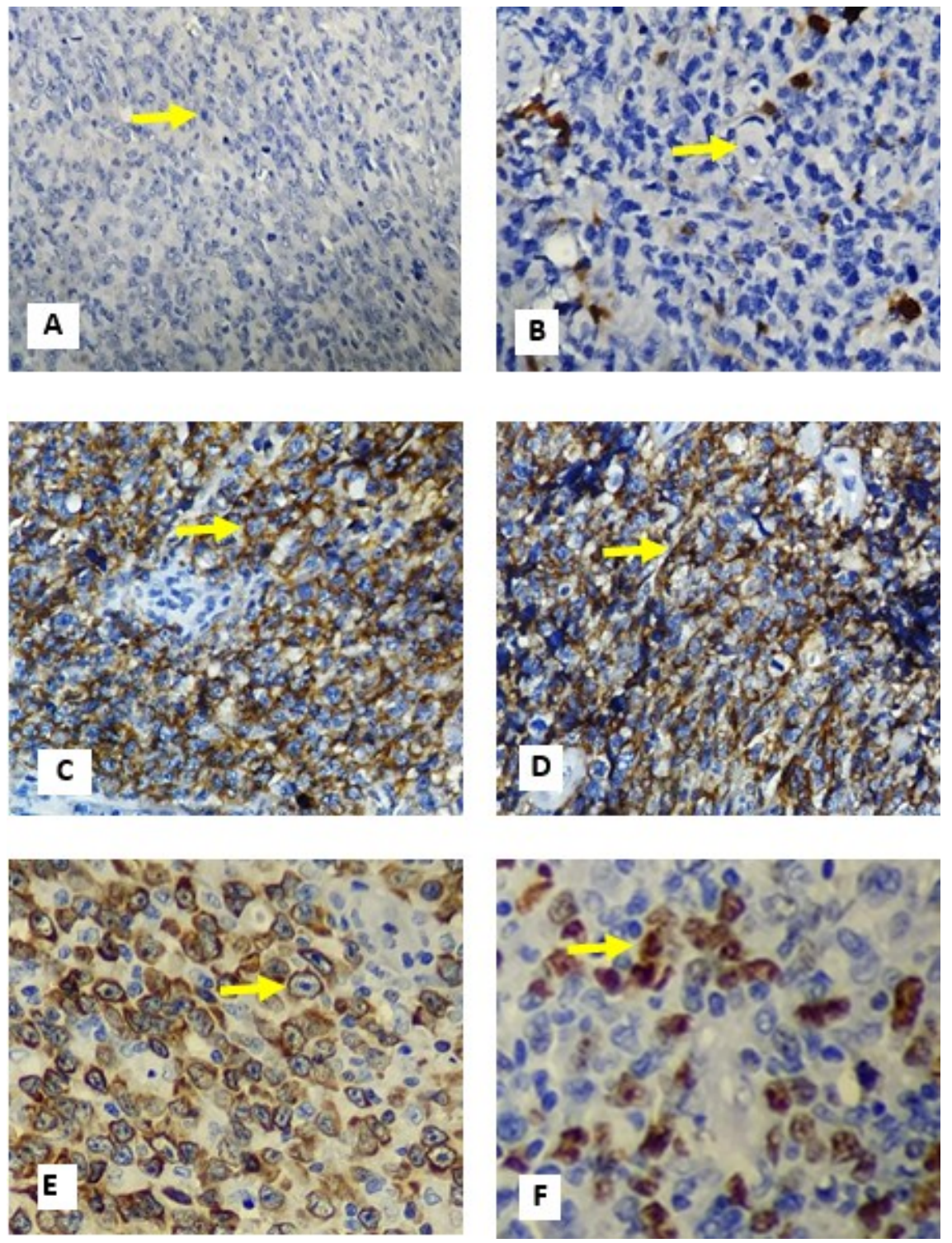

Gambar 3. Profil IHK primary cutaneous diffuse large B-cell lymphoma

Keterangan: A dan B. Penanda Melan A dan S100 tidak terekspresi pada sel tumor yang berwarna biru (panah kuning); C dan D. Penanda LCA dan CD20 terekspresi positif kuat berwarna coklat pada membran dan sitoplasma sel tumor (panah kuning); E. Penanda Bcl2 terekspresi coklat, dengan intensitas kuat dan difus pada membran inti sel tumor (panah kuning). F. Penanda Ki67

\section{Pembahasan}

Primary cutaneous B cell lymphoma (PCBCL) terjadi pada $20 \%$ dari semua limfoma primer kulit. Data dari Laboratorium Patologi Anatomi RSUD Dr. Saiful Anwar Malang pada tahun 2016-2018 menunjukkan bahwa limfoma primer kulit tergolong penyakit yang langka. ${ }^{5}$ Angka kejadian PCBCL sekitar $29 \%$ yaitu 3,1 kasus per 1 juta populasi setiap tahunnya. ${ }^{2,3,6}$ Pengelompokan primary cutaneous $B$ - cell lymphoma terbaru didasar- kan pada klasifikasi World Health Organization-European Organization for Research dan Treatment of Cancer (WHOEORTC) tahun 2017.1,2,7 Pada klasifikasi WHO-EORTC ini PCBCL dibedakan menjadi 3 kelompok utama yaitu; primary cutaneous marginal zone lymphoma (PCMZL), primary cutaneous follicle-center lymphoma (PCFCL) dan primary cutaneous diffuse large B-cell lymphoma-leg type (PCDLBCL- leg type). $1,2,3,7,8$ 
Berbeda dengan low grade $\mathrm{PCBCL}$ yaitu PCMZL dan PCFCL yang sering bermanifestasi pada usia anak-anak hingga dewasa muda, PCDLBCL-leg type terjadi pada orang tua di atas 60 tahun dengan angka ketahanan hidup 5 tahun $55 \%, 7,8,9,10$ Primary cutaneous DLBCL-leg type lebih banyak terjadi pada wanita dengan rasio 34:1 dibanding laki-laki. ${ }^{8}$ Etiologi dan patogenesis PCBCL belum diketahui pasti, namun Borrelia burgdorferi dicurigai sebagai penyebab utama, terutama pada subtipe PCMZL. Studi lain menyebutkan bahwa PCBCL dapat diakibatkan dari penggunaan tato, skar pasca herpes zoster, injeksi antigen, akupuntur, reaksi gigitan serangga persisten serta lesi terlokalisir akibat stimulus yang tidak diketahui. ${ }^{9}$

Pada kasus ini, pasien adalah seorang laki-laki usia 46 tahun, berbeda dengan data dari WHO yang menunjukkan bahwa penderita terbanyak PCDLBCL-leg type adalah wanita dan berusia di atas 60 tahun, dengan usia median 78 tahun. 2,8 Riwayat stimulus etiologi penyakit ini tidak ditemukan, namun kemungkinan infeksi lama oleh Borrelia burgdorferi belum dapat disingkirkan. ${ }^{2}$ Secara teori PCDLBCL-leg type cepat bertumbuh dengan perdileksi ekstrimitas bawah bagian distal. Gambaran klinis berupa plak atau nodul/tumor yang tunggal atau multipel bergerombol berwarna merah kebiruan. Sering terdapat ulserasi, namun dapat menyerupai suatu ulserasi yang disebabkan insufisiensi vena yang kronis. ${ }^{3}$

Diagnosis histopatologi $\mathrm{PCBCL}$ ditegakkan dalam 3 tahap, dengan syarat telah disingkirkan diagnosis lain selain lesi limfoproliferatif. Tahap pertama adalah untuk menentukan apakah lesi limfoproliferatif yang bersifat jinak atau ganas; yang kedua adalah untuk memutuskan apakah itu adalah sel B, sel $\mathrm{T}$ atau natural killer cell (NK-sel) dan tahap terakhir adalah untuk mengklasifikasikan subtipe limfoma sel B. Biopsi adalah langkah pertama yang dilakukan dalam menegakkan diagnosis PCBCL. Biopsi dilakukan dengan ukuran minimal $5 \mathrm{~mm}$ dan harus mencapai jaringan subkutan. Tumor yang berukuran kecil dapat dilakukan eksisi total.

Gambaran arsitektur histopatologi berpola nodular/difus serta imunofenotipik sangat penting untuk klasifikasi PCBCL. Pemeriksaan imunohistokimia (IHK) pada PCBCL dengan panel antibodi CD20, CD79a, CD10, Bcl6, MUM1/IRF4, serta kappa/lambda dan Bcl2, sangat membantu diagnosis.2,4 Sediaan histopatologi yang memperlihatkan morfologi sel tetap diperlukan untuk mengkonfirmasi diagnosis, di samping panel IHK untuk limfoma kutan. Hal ini karena sel B yang reaktif dari sediaan blind biopsy kulit normal juga dapat menunjukkan pemeriksaan IHK yang terekspresi positif terhadap LCA, CD20 dan CD79a serta CD3 negatif. Clinicopathological Conference (CPC) adalah sarana untuk mencapai sekaligus mempercepat diagnosis yang akurat dengan korelasi klinis multidisipliner dan hasil histopatologi yang ditemukan.

Primary cutaneous diffuse large $B$ cell lymphoma-leg type adalah DLBCL yang secara eksklusif terdiri dari sentroblas dan imunoblas serta berlokasi di kaki. Gambaran histopatologi dengan pewarnaan hematoxylineosin (HE) pada PCBCL menunjukkan adanya pita kolagen (collagen band) di superfisial dermis yang disebut grenz zone yang memisahkan epidermis dari infiltrat limfoid dermal. Lesi pada stadium awal penyakit ini berupa infiltrat perivaskular ireguler/nodular dan infiltrat periadneksa. Limfosit T reaktif dapat terlihat di perifer atau di antara sel neoplastik. Pada lesi yang lanjut terlihat infiltrat sel yang lebih difus dari dermis hingga subkutan. 2,4 Infiltrat berupa sel blas besar yang menyerupai sentroblas (inti bulat, anak inti di tepi membran sel) atau imunoblas (berukuran besar, inti bulat dengan anak inti menonjol di tengah). 
Kadang ditemukan sel anaplastik berbentuk aneh, konfigurasi tidak teratur, biasanya dengan sitoplasma luas serta sel-sel tumor yang mengalami apoptosis. ${ }^{8}$ Primary cutaneous DLBCL-leg type ditandai dengan infiltrat difus sel limfoid atipik tersusun di dermis dengan perluasan ke subkutis. Infiltrat limfoid PCBCL pada umumnya tebal, asimetris, nodular atau difus, dan kadang lebih banyak di dermis profunda. Gambaran ini disebut "bottom heavy pattern".

Gambaran histopatologi pada spesimen biopsi pasien ini didominasi oleh proliferasi sel yang berinti bulat, berukuran besar sehingga tampak lebih pleiomorfik. Dari gambaran tersebut diagnosis banding secara histopatologi adalah melanoma maligna tipe amelanotik. Melanoma maligna adalah tumor ganas dari sel melanosit dengan ciri khas mengandung pigmen bergranul kecoklatan, namun pada tipe amelanotik dapat tidak menunjukkan adanya pigmen. Melanoma sering kali menjadi the great imitator dari berbagai tumor ganas karena inti selnya dapat menyerupai bentuk kumparan, bulat dan besar, epitelioid bahkan berukuran kecil.
Pola penyebaran lokasi tumor pada pasien ini adalah dari tungkai bawah ke kelenjar getah bening inguinal dan leher, serupa dengan perjalanan metastasis melanoma maligna. ${ }^{11}$ Peran pemeriksaan IHK menjadi penting karena melanoma maligna memiliki profil imunofenotipik positif terhadap Melan A, S100 dan HMB45, sedangkan pada pasien tersebut menunjukkan ekspresi negatif terhadap Melan A dan S100. Diagnosis melanoma tipe amelanotik kemudian dapat disingkirkan. Hasil pemeriksaan IHK lain pada pasien tersebut yaitu LCA dan CD20 yang tersekspresi positif kuat mendukung limfoma kutan tipe sel B.

Klasifikasi limfoma kutan dengan manifestasi primer pada kulit dapat dilihat pada Tabel 1. Pada klasifikasi ini juga dibedakan 3 golongan utama tipe PCBCL yaitu : primary cutaneous marginal zone $B$ cell lymphoma (PCMZL), primary cutaneous follicle center lymphoma (PCFCL), dan primary cutaneous diffuse large $B$-cell lymphoma-leg type (PCDLBCL-leg type).2,8,9,10

Tabel 1. Klasifikasi limfoma kutan dengan manifestasi primer pada kulit (WHO-EORTC Classification for Cutaneous Lymphomas $)^{6}$

\begin{tabular}{|c|c|c|c|}
\hline WHO 2017 & PCMZL & PCFCL & PC DLBCL-LT \\
\hline Gambaran klinis & $\begin{array}{l}\text { soliter, papul multipel, } \\
\text { plak, nodul, } \\
\text { terlokalisir di kaki, } \\
\text { sering rekuren, } \\
\text { jarang menyebar }\end{array}$ & $\begin{array}{l}\text { soliter atau } \\
\text { berkelompok di kepala } \\
\text { dan badan, rekuren } \\
20 \%\end{array}$ & $\begin{array}{l}\text { soliter atau multipel } \\
\text { tumor terutama di kaki } \\
\text { jarang di tempat lain, } \\
\text { sering rekuren dan } \\
\text { penyebaran } \\
\text { ekstrakutan }\end{array}$ \\
\hline Histopatologi & $\begin{array}{l}\text { infiltrat difus/macula } \\
\text { terdiri dari sel B kecil, } \\
\text { termasuk sel marginal } \\
\text { zone, limfoplasmasitoid, } \\
\text { sel plasma }\end{array}$ & $\begin{array}{l}\text { folikular, folikular-difus, } \\
\text { atau infiltrat difus } \\
\text { terdiri dari sel } \\
\text { neoplastik tipe folikel, } \\
\text { campuran sentrosit - } \\
\text { sentroblas dengan } \\
\text { jumlah bervariasi }\end{array}$ & $\begin{array}{l}\text { infiltrat difus, terdiri } \\
\text { dari sel neoplastik tipe } \\
\text { sentroblas dan } \\
\text { immunoblas yang } \\
\text { berkonfluen }\end{array}$ \\
\hline Immunofenotipik & $\begin{array}{l}\mathrm{CD} 20+, \mathrm{CD} 79 \mathrm{a}+, \mathrm{Bcl}_{2}+ \\
\text { CD5-, cyclinD1-, BcL } 6^{-}, \\
\text {CD10-, MUM1- }\end{array}$ & $\begin{array}{l}\text { CD20+, CD79a+, Bcl6 } \\
+, \text { Bcl } 2-, \text { MUM1-, } \\
\text { CD10+/-, }\end{array}$ & $\begin{array}{l}\mathrm{CD} 20+, \mathrm{CD}_{99} \mathrm{a}^{+}, \mathrm{BCl}_{6-} \\
\text { /+, } \mathrm{CD} 10-, \mathrm{BCl}_{2}+\mathrm{kuat} \\
\text { dan difus, MUM1+ }\end{array}$ \\
\hline Prognosis & $\begin{array}{l}\text { 5-year survival rate } \\
>95 \%\end{array}$ & $95 \%$ & $\begin{array}{l}50 \% \\
\text { Meninggal dalam } 17 \\
\text { bulan tanpa terapi }\end{array}$ \\
\hline
\end{tabular}


Primary cutaneous large $B$ cell lymphoma-leg type, biasanya terjadi pada kaki dan jarang berlokasi di organ lain, sesuai dengan gambaran klinis pasien yang menyatakan bahwa tumor ini telah diderita selama 1,5 tahun, berawal pada tungkai bawah kemudian menyebar ke ekstrakutan tanpa pengobatan.

Pada Tabel 1 dapat dilihat bahwa ketiga limfoma kutan primer pada sel B dapat menunjukkan gambaran arsitektur yang difus. Primary cutaneous marginal zone $B$ cell lymphoma memiliki ciri morfologi sel berinti bulat, limfoplasmasitoid, PCFCL tipe difus memiliki morfologi sel yang didominasi tipe sentrosit-sentroblas, sedangkan PCDLBCLleg type yang memiliki morfologi sel sentroblas-munoblas. Kemiripan arsitektur PCDLBCL-leg type dengan PCFCL tipe difus kemudian disingkirkan dengan pemeriksaan IHK.

Imunohistokimia (IHK) adalah suatu metode yang menggunakan antibodi monoklonal dan poliklonal untuk mendeteksi antigen spesifik pada suatu jaringan tumor, sehingga dijadikan sebagai gold standart diagnosis limfoma kutan. Jaringan hasil biopsi diproses menjadi beberapa bagian dengan mikrotom kemudian diinkubasi menggunakan antibodi yang sesuai. Waktu untuk inkubasi disesuaikan dengan titer antibodi, semakin tinggi titer antibodi semakin pendek waktu inkubasi. Untuk antibodi primer waktu inkubasi dapat bervariasi, dan waktu yang paling sering digunakan adalah 10-30 menit. Reaksi antigen antibodi lebih cepat mencapai keseimbangan pada suhu $37^{\circ} \mathrm{C}$ dibandingkan dengan suhu ruangan. Sel terekspresi positif bila terwarnai dengan baik dan terlihat jelas, sedangkan negatif bila warna kabur maupun tidak spesifik. Kontrol digunakan untuk membandingkan, mengkonfirmasi spesifisitas dan sensitivitas dari proses pewarnaan. 13,14

Cluster Designation atau penanda CD atau $C D$ marker adalah penanda yang digunakan untuk diferensiasi cluster pada manusia. Penanda CD adalah antibodi monoklonal terhadap molekul antigen permukaan baik yang terdapat pada leukosit maupun antigen yang terdapat pada sel lainnya. Penggunaan nomenklatur penanda CD pertama kali pada tahun 1982 di First International Workshop dan Conference on Human Leukocyte Differentiation Antigens (HLDA). ${ }^{15}$

Sel-sel tumor PCBCL memiliki karakteristik fenotipik dengan ekspresi penanda sel $B(C D 19, C D 20, C D 22$ dan CD79a) dengan ekspresi yang kuat. Tingginya proliferasi pada kelompok ini dilihat dari Ki67 atau MIB-1. 2,4,8

Berikut beberapa penanda yang digunakan untuk PCBCL dan diagnosis bandingnya: 1. LCA atau CD45 untuk konfirmasi asal sel limfoid, CD20 dan/ CD79a untuk konfirmasi asal sel $B$ dan $\mathrm{CD} 3$ untuk penilaian sejumlah sel T reaktif campuran; 2. Folikel-folikel atau jaring dendritik divisualisasi dengan CD21; 3. Ki-67 untuk konfirmasi indeks proliferasi sel tumor; 4. $\mathrm{Bcl}_{2}, \mathrm{Bcl}_{6}$, CD10, MUM-1, FOXP1: diferensiasi berbagai jenis PCBCL, limfoma kutan sekunder dari kelenjar getah bening/organ lain; 5 . Immunoglobulin permukaan dan sitoplasma (slg \& clg) : konfirmasi asal sel dan deteksi ekspresi lg.2,4

Primary cutaneous diffuse large B-cell lymphoma-leg type merupakan kelompok tumor yang heterogen secara klinis dan genetik. Karakteristik sel tumor PCDLBCL-leg type adalah penanda sel B seperti CD19, CD20, CD22 dan CD79a yang terekspresi positif. $\mathrm{BCl}_{2}, \mathrm{MUM}-1$ dan IgM, diekspresikan kuat, sedangkan $\mathrm{Bcl}_{6}$ dan $\mathrm{CD} 10$ jarang sekali diekspresikan, atau diekspresikan lemah. ${ }^{2}$ FOX-P1 (salah satu faktor transkripsi FOX-P) diekspresikan pada beberapa kasus. Fox-P1 diekspresikan oleh sel B yang teraktivasi, tetapi diekspresikan berlebihan pada subset PCDLBCL-leg type. 
Proliferasi yang tinggi dapat dilihat dengan MIB-1 atau Ki67. Indeks proliferasi pada DLBCL dihitung dari Ki-67 yang positif di atas $40 \%$, bahkan sering lebih dari $90 \%$, yang menunjukkan prognosis yang buruk. Pasien ini menunjukkan hasil pemeriksaan IHK yang sesuai dengan PCDLBCL-leg type yaitu $\mathrm{BCL}_{2}$ yang terekspresi dengan kuat dan difus serta Ki67 $>40 \%$.

Pada PCMZL, penanda sel B yaitu CD20, CD79a terekspresi positif, sedangkan penanda CD5, CD10, Bcl 6 negatif. CD10 dan $\mathrm{BCl}_{6}$ penting untuk membedakan PCMZL dengan PCFCL. Pada pulasan IHK dengan Ki67 (MIB-1) ditemukan proliferasi limfosit sel $B$ monoklonal yang mengumpul di perifer agregat seluler. ${ }^{9}$ Pada PCFCL, penanda CD20, dan CD79a terekspresi positif baik pada tipe difus maupun tipe folikular. Pada PCFCL dengan pola pertumbuhan folikular, penanda sel germinal center yaitu CD10 dan $\mathrm{Bcl}_{6}$ terekspresi positif, sedangkan CD10 pada pola difus negatif. Pada pola campuran folikular dan difus, didapatkan $\mathrm{CD}_{2} 1^{+} \mathrm{di}$ perifer. Sekitar $90 \% \mathrm{Bcl}_{2}$ tidak diekspresikan oleh sel tumor PCFCL.2,4,10

Primary cutaneous follicle center-cell lymphoma (PCFCL) memiliki prognosis sangat baik, dengan angka kelangsungan hidup 5 tahun di atas 95\%.8 Pasien dengan PCFCL dengan lesi kulit dan keterlibatan sumsum tulang mempunyai prognosis yang jelek dibandingkan dengan PCFCL yang bermanifestasi pada lesi kulit saja. Primary menunjukkan perjalanan klinis dengan kecenderungan untuk kambuh, namun prognosisnya baik dengan angka kelangsungan hidup 5 tahun yaitu 90 dan $100 \%$. Pada beberapa kasus dapat bertransformasi menjadi PCDLBCL, namun angka kejadiannya sangat jarang. 9

Diagnosis banding lain dari limfoma jenis sel besar pada kutan yang lebih jarang dan dapat menunjukkan kemiripan dengan PCDLBCL leg-type adalah PCDLBCL-others. Secara definisi PCDLBCL-others merupakan neoplasma sel limfosit B dengan ukuran inti sama atau lebih besar dari makrofag atau dua kali ukuran limfosit dengan pola pertumbuhan difus. ${ }^{1,2}$ Limfoma jenis ini terdiri dari varian morfologi DLBCL pada kutan yang tidak memenuhi kriteria untuk PCDLBCL-leg type maupun PCFCL tipe difus dan bersifat lebih agresif yaitu DLBCL varian T-celll hystiocyte rich, Plasmablastic lymphoma dan DLBCL varian anaplastik. 8,12

Terapi yang efektif untuk penderita PCDLBCL-leg type adalah seperti pada DLBCL sistemik yaitu kemoterapi berbasis Anthracycline. AntiCD20 antibodi-sistemik (Rituximab) sering digunakan bersama regimen kemoterapi Cyclophosphamide, Hydroxydaunorubicin, Oncovin (vincristine) dan Prednison/Prednisolon (CHOP) atau CHOP-like chemotherapy.1,6,7,12 Berbeda dengan PCBCL tipe PCMZL dan PCFCL, prognosis PCDLBCL-leg type lebih buruk, dengan rerata angka ketahanan hidup 5 tahun adalah 50\% (20-60\%). ${ }^{1}$ Pasien ini tidak menjalani pemeriksaan diagnosis selama 1,5 tahun dan akhirnya meninggal sebelum mendapatkan terapi.

\section{Kesimpulan}

Pada kasus ini dilaporkan seorang lakilaki dengan massa pada regio tungkai bawah yang tidak memiliki riwayat keterlibatan pada ekstrakutan sebelumnya, dengan gambaran histopatologi berupa proliferasi difus sel-sel berinti bulat, yang dikenal dengan sebutan malignant round cell tumor, terdiri dari campuran imunoblas dan sentroblas, sehingga perlu dipertimbangkan diagnosis PCDLBCL-leg type. Dengan adanya laporan kasus ini diketahui bahwa peran IHK sangat menentukan diagnosis definitif DLBCL-leg type serta menyingkirkan beberapa diagnosis banding di antaranya Melanoma Maligna maupun subtipe limfoma kutan jenis sel $B$ lain yang memiliki tatalaksana dan prognosis berbeda. 


\section{Ucapan Terima kasih}

Terima kasih kepada dr Wisnubroto, SpB. (Onk) dan tim CPC onkologi RSUD Dr. Saiful Anwar Malang.

\section{Daftar Pustaka}

1. Wilemze $R$, Vergier $B$, Duncan $L M$. Primary Cutaneous Diffuse Large B Cell Lymphoma, Leg Type. In : Swerdlow SH, Campo E, Harris NL, Jaffe ES, Pileri $\mathrm{SA}$, Stein $\mathrm{H}$, Thiele $\mathrm{J}$, et al. (Editors). WHO Classification of Haematopoietic Tumours. Revised $4^{\text {th }}$ ed. Lyon: IARC Press. 2017. P. 304-5.

2. Wilemze $R$, Maarten, Vermeer, Jansen PM. Primary Cutaneous B Cell Lymphoma. In : Jaffe ES, Arber DA, Campo E, Harris NL, Quintanella Martinez L (Editors). Haematopathology. Philadelphia: Elsevier. 2017. P. 369-81.

3. Bargot $M$, Stadler R. Cutaneous Lymphoma. In : Kang S, Amagai $M$, Bruckner AL, Enk AH, Margolis DJ, McMikhael AJ, Orringer JS (Editor). Fitzpatrick's Dermatology in General Medicine. $9^{\text {th }}$ ed. New York: McGrawHill. 2019. P. 2097-102.

4. Wilemze R, Berti E, Facchetti F, Kempf W, Jaffe ES. Tumours of Haematopoietic Lymphoid Origin: Introduction. In : Elder $D E$, Massi D, Scolyer RA, Wilemze $R$ (Editors). WHO Classification of Skin Tumours. $4^{\text {th }}$ ed. Lyon: IARC Press. 2018. P. 224-5.

5. Retnani DP. Peran Aspek Klinikopatologi, Imunofenotip dan Analisis Klonalitas untuk Menegakkan Diagnosis Mycosis Fungoides. Majalah Kesehatan. 2020; 7 (1):59-71.

6. Lima M. Cutaneous Primary B-Cell Lymphomas: from Diagnosis to Treatment. An Bras Dermatol. 2015; 90 (5):687-706.
7. Calonje E, Goodlad J. Cutaneous Lymphoproliferative Diseases and Related Disorders. In : Calonje E, Brenn T, Lazar A, Billings S (Editor). McKee's Pathology of the Skin with Clinical Correlations. $5^{\text {th }}$ ed. China: Elsevier Saunders. 2020. P. 1460-8.

8. Wilemze R, Battistella M, Duncan LM, Vergier B. Primary Cutaneous Diffuse Large B Cell Lymphoma, Leg Type. In : Elder DE, Massi D, Scolyer RA, Wilemze $\mathrm{R}$ (Editors). WHO Classification of Skin Tumours. $4^{\text {th }}$ ed. Lyon: IARC Press. 2018. P. 260-1.

9. Kempf W, Duncan LM, Swerdlow SH, Wilemze R. Primary Cutaneous Marginal Zone (MALT) Lymphoma. In: Elder DE, Massi D, Scolyer RA, Wilemze R (Editor). WHO Classification of Skin Tumours. $4^{\text {th }}$ ed. Lyon: IARC Press. 2018. P. 256-7.

10. Wilemze R, Santucci M, Swerdlow SH, Vergier B. Primary Cutaneous Follicle Centre. In: Elder DE, Massi D, Scolyer RA, Wilemze $\mathrm{R}$ (Editors). WHO Classification of Skin Tumours. $4^{\text {th }}$ ed. Lyon: IARC Press. 2018. P. 258-9.

11. Elder DE, Murphy GF. AFIP Atlas of Tumor Pathology. Melanocytic Tumors of the Skin. Series 4. Washington DC : American Registry of Pathology. 2010. p. 418-22.

12. Cerroni L. Large B Cell Lymphoma. Proceeding Book of NUHS Haematolymphoid Pathology Course. Singapore. May 2-4th 2019; 615-21.

13. Dewar R, Andea AA, Guitart J, Arber DA, Weiss LM. Best Practices in Diagnosis Immunohistochemistry, Workup of Cutaneous Lymphoid Lesions in the Diagnosis of Primary Cutaneous Lymphoma. Arch Pathol Lab Med. 2015; 139:338-50. 
14. Pittaluga S, Barry TS, Rafeld $M$. Immunohistochemistry of Hematopathology Laboratory In : Jaffe ES, Arber DA, Campo E, Harris NL, Quintanella - Martinez L (Editors). Haematopathology. Philadelphia: Elsevier. 2017. P. 41-4.
15. Engel $P$, Boumsell $L$, Balderas $R$, Bensussan A, Gattei V, Horejsi V, et al. CD Nomenclature 2015: Human Leukocyte Differentiation Antigen Workshops as a Driving Force in Immunology. J Immunol . 2015; 195 (10):4555-63. DOI: https:// doi.org/10.4049/jimmunol.1502033. 